Article

\title{
Applying a Relationally and Socially Embedded Decision Framework to Solar Photovoltaic Adoption: A Conceptual Exploration
}

\author{
Chelsea Schelly ${ }^{1, *(D)}$, Don Lee ${ }^{1}(\mathbb{D})$ Elise Matz ${ }^{2}$ and Joshua M. Pearce ${ }^{3,4}$ (D) \\ 1 Department of Social Sciences, Michigan Technological University, Houghton, MI 49931, USA; \\ dolee@mtu.edu \\ 2 Visiting Scholar, Michigan Technological University, Houghton, MI 49931, USA; elisematz@gmail.com \\ 3 Department of Materials Science \& Engineering, Michigan Technological University, Houghton, MI 49931, USA; \\ pearce@mtu.edu \\ 4 Department of Electrical \& Computer Engineering, Michigan Technological University, Houghton, MI 49931, USA \\ * Correspondence: cschelly@mtu.edu
}

Citation: Schelly, C.; Lee, D.; Matz,

E.; Pearce, J.M. Applying a

Relationally and Socially Embedded

Decision Framework to Solar

Photovoltaic Adoption: A Conceptual

Exploration. Sustainability 2021, 13,

711. https://doi.org/10.3390/

su13020711

Received: 29 November 2020

Accepted: 9 January 2021

Published: 13 January 2021

Publisher's Note: MDPI stays neutral with regard to jurisdictional clai$\mathrm{ms}$ in published maps and institutional affiliations.

Copyright: $(\odot 2021$ by the authors. Licensee MDPI, Basel, Switzerland. This article is an open access article distributed under the terms and conditions of the Creative Commons Attribution (CC BY) license (https:// creativecommons.org/licenses/by/ $4.0 /)$.

\begin{abstract}
Solar photovoltaic (PV) energy technology can play a key role in decreasing the amount of carbon emissions associated with electrical energy production, while also providing an economically justifiable alternative to fossil fuel production. Solar energy technology is also extremely flexible in terms of the size and siting of technological development. Large scale PV farms, however, require access to large tracts of land, which can create community-scale conflict over siting solar energy development projects. While previous scholarship offers frameworks for understanding the mechanisms at play in socio-technological system transitions, including the renewable energy transition, those frameworks fail to center community priorities, values, and concerns, and therefore often do not provide an effective means of addressing community conflict over solar siting. This paper provides a conceptual exploration of how a proposed framework can guide decision making for solar development across multiple scales and settings, while also illuminating the potential barriers and bottlenecks that may limit the potential of solar energy development to occur in scales and forms that receive community acceptance and at the pace necessary to address the greenhouse gas emissions currently contributing to the rapidly changing global climate.
\end{abstract}

Keywords: energy decision making; energy transitions; photovoltaics; solar energy; sustainability; community; energy democracy; energy security; energy sovereignty

\section{Introduction}

Solar photovoltaic (PV) energy has undergone an incredibly rapid industrial learning curve [1-3], resulting in continuous cost declines [4,5]. The International Renewable Energy Agency (IRENA) confidently predicts that PV prices will fall by another $60 \%$ in the next decade [6]. Even without expected future cost reductions, any scale of PV, from residential to industrial, provides a levelized cost of electricity (LCOE) [7] lower than the net-metered cost of grid electricity [8-10]. PV economics ensure that coal-fired electricity is no longer economically competitive, and solar is now normally the least costly electricity source $[11,12]$. In addition, there are several technical improvements like black silicon $[13,14]$ and bifacial PV $[15,16]$ that are poised to gain market control and further drive down costs [17]. Unsurprisingly, solar PV is the fastest growing electricity source, with capacity reaching about $505 \mathrm{GW}$, or $2 \%$ of global electricity production, in 2018 [18], and reaching at least 627 GW by 2019 [19]. The rapid improvements in PV and energy storage technologies are arguably outpacing social recognition of the urgency with which energy systems need to transition to avoid the worst of the catastrophic impacts associated with the continued use of fossil fuels for energy production and the policy tools being used to propel this transition. For example, despite the fact that the LCOE of community and 
utility-scale solar is competitive with coal and natural gas, a combined $65 \%$ of Americans think that climate policies would have no impact or would hurt the economy, and while an overwhelming majority of Americans would like to see more reliance on solar and wind energy, 29\% believe that climate policies will make no difference for the environment, and $15 \%$ believe that climate policies will do the environment more harm than good [20]. This paper centers on these social considerations and presents a framework that can incorporate social values in ways that may improve the speed and the outcomes of this transition.

PV has other advantages besides costs. Renewable energy technologies like solar PV may create emissions during manufacturing and installation but produce emissionfree electrical energy once installed and, overall, have an excellent ecological balance sheet [21]. The generation and delivery of electric power using conventional thermal fossilfuel driven power plants consumes almost two-thirds of the primary energy delivered to the grid [22,23]. Globally, nearly a billion metric tons of carbon dioxide equivalents can be attributed to "compensatory emissions" related to a lack of efficiency in generation and transmission. Forty to fifty percent of those emissions can be cut by improving grid efficiencies [24], which could be achieved with distributed energy resources. PV is inherently distributed and modular so it can be located near or even on the structure of the electricity consumer to provide for energy needs even as loads shift over time. This distributed generation (DG) with PV has several technical advantages: (i) improved reliability $[25,26]$, (ii) enhanced voltage profiles and power quality [27], (iii) reduced transmission and distribution losses [28], and the concomitant transmission and distribution infrastructures deferments. In addition, PV has been long established as a sustainable energy source [29], with well-documented superior environmental performance to conventional sources of electricity, as directly generating electricity from solar energy is free from fossil energy consumption and greenhouse gas (GHG) emissions during its operation. When compared to the advantages of solar energy, fossil fuel-based energy generation no longer makes technical or economic sense.

Despite these advantages, PV continues to face challenges that limit or slow its development. Solar is an intermittent resource (e.g., it only works when the sun is shining). Solar energy is diffuse, so PV equipment requires large surface areas. According to the Energy Information Administration, the average American household uses $877 \mathrm{kWh}$ of electricity per month [30]. In general, the average non-shaded residential home has more than enough roof area to meet its energy needs; other structures, such as large retail stores, would need to start covering the parking lots with awnings to meet energy needs with distributed PV [31]. Densely populated cities do not have enough surface area available for PV to meet their electricity needs (let alone transport and heating needs covered by vehicle electrification and heat pumps, respectively). Large areas of open land are needed for PV [32], and they are generally located in rural areas.

Due to these needs, land use conflicts are a growing problem for large-scale PV. These siting conflicts were once relegated to wind farm development [33-36], but now shape public opinion regarding solar energy projects $[37,38]$. Using solar may be technically more efficient, as well as having a lower LCOE than conventional power plants [7], but conflict over siting-questions about where to locate what size PV systems to support whose energy needs-remains an issue.

Across the United States, individual states as well as local units of government have set goals to reduce or eliminate carbon emissions, either via legislation or executive action [39]. The utility sector is responding accordingly. In November 2020, six Midwest utility holding companies said they expect to retire a combined total of $5.8 \mathrm{GW}$ of coal-fired capacity by the years 2022-2023 and, over the next several years, buy or install $4 \mathrm{GW}$ of solar generation, 3.6 GW of wind generation, and just over $1 \mathrm{GW}$ of electric battery storage [40]. Rarely included in such breathless announcements is the fact that developers and utilities have often yet to secure the requisite number of acres to host the utility-scale PV developments upon which their projections rely. 
Options like rooftop solar and community-scale solar developments, which tend to distribute the economic benefits of renewable generation more equitably than utility-scale developments, are popular with host communities, as are efforts to site larger developments on brownfields and other post-industrial sites [41]. There is little doubt, however, that achieving complete independence from fossil fuels in electricity production, transportation, and heating, will require large-scale development, even if the amount of land necessary and which types of land to be utilized is disputed (i.e., agricultural land, ecologically sensitive land, and previously forested land are contested). Given these variables, the question of how to achieve a renewable energy transition in an equitable and cost-effective way has been the purview of monopoly utilities, state public utility commissions, lawmakers, and federal regulators across much of the United States. This top-down regime, a product of the historical need for large, up-front capital investment in energy production and distribution, has rarely given serious credence to the priorities of the communities it serves [42]. The need, however, to site utility-scale generation, as well as the rapid innovation and accessibility of distributed generation technologies, is altering consumers' relationships with their energy providers. In a sense, the renewable energy transition has forced utilities back to the negotiating table, as communities and individual consumers reexamine a century-old unwritten compact about the rights and responsibilities of each.

In this new dynamic, the framework explained and applied below could help improve decision making that increases the deployment velocity of PV by attempting something radical: centering energy policy in the nexus of the cultural, ecological, and economic priorities of the communities that produce and consume it. This could help provide direction for community decision-makers and, by revealing the complexity and web of interconnected factors that matter, could lead to solutions that ensure greater cultural and economic resilience. This proposed framework is explored conceptually below through application to the questions and decision-making factors that may shape the priorities and choices a community makes regarding solar energy development.

\section{Socio-Technological Systems Transitions Frameworks}

Arguably, the most well-developed framework for examining socio-technological system transitions is the multi-level perspective [43-46], also known as the MLP. The MLP conceptualizes transitions in terms of interactions across actors and institutions and argues that "sociotechnical transitions come about through interacting processes within and between the incumbent regime, radical niche-innovations, and the sociotechnical landscape" [43] (p. 225). MLP is a dominating framework for exploring the various mechanisms and pathways involved in successful transitions to renewable energy adoption in communities [47] and across the "sociotechnical landscape."

The MLP is in some ways a critique and response to Christensen's early innovations framework, which focused on disruption from niche innovations challenging incumbent rule [48]. Christensen's framework focused on disruptive technology, while MLP "broadens the unit of analysis from technological products to sociotechnical systems that provide societal functions" and that "consist of an interdependent and co-evolving mix of technologies, supply chains, infrastructures, markets, regulations, user practices, and cultural meanings" [43] (p. 225). The MLP aims to broaden the factors considered as analytically relevant to understand transitions to include "consumption, cultural, and socio-political dimensions" [43] (p. 227).

Previous scholarship based on the MLP framework includes work examining the role of power and politics [45]. Based on employing a political economy perspective, the MLP can be utilized in a way that is attentive to how incumbent regime actors (those who benefit financially from continued reliance on fossil fuels for electrical energy) can shape discourse, policy, and possibilities in the energy transition through multiple forms of power, including instrumental, discursive, material, and institutional. The MLP also allows for considerations of resistance to incumbent regimes from both niche-innovations and the broader socio-technological landscape. Analyzing the power and interests of the 
"regime" construct reveals a failure to account for "problems of agency and the politics of transitions" [49] (pp. 143-144), as the potential involvement and influence of collective groups of actors has not been researched adequately, according to some scholars, which is critical in understanding the nuances of socio-technological energy transitions, particularly in previously colonized country contexts [49].

By starting with an emphasis on "socio-technical systems," however, the MLP is inherently focused on material systems and the institutional systems that govern them. There is less room in MLP for considering the role of cultural values, priorities, and identities in informing and directing transitions in grounded, socially embedded contexts. Arguably, the MLP framework allows inadequate space for conceptualizing how real people and their real lived priorities can inform decision making in energy transitions (and other socio-technological system transitions). The framework presented here attempts to address these critical deficiencies, as they are applicable across the spectrum of development stages, with particular focus on accounting for agency through the prioritization of community values and the subjugation of technical, economic, or political feasibility to community priorities.

The framework described below is inspired by the medicine wheel or sacred hoop, representing the philosophy adopted by many Indigenous Nations of being in balance through life's natural and cyclical transitions. As a whole, the framework is intended to conceptually represent knowledge and relations while maintaining balance through continuous transitions of all kinds. These teachings offer a guide for finding a respectful and ethical path through a socio-technological system change.

The relationships among the interconnections in Figure 1 start with four foundational questions (as described below) [50]. These four foundational questions guide the application of this framework. This framework also suggests particular research questions (RQ) that can guide empirical research employing this framework (as also explored below):

RQ 1.1: What community visions, values, perceptions, and priorities are associated with which risks, barriers, and opportunities for renewable energy system transitions?

RQ 1.2: How does this vary across the community context?

$\mathrm{RQ}$ 1.3: What trade-offs or compromises do communities make when making energy decisions?

RQ 2.0: What socio-cultural, technical, biophysical, and regulatory variables facilitate or impede renewable energy transitions given the benefits, risks, and opportunities associated with renewable energy development?

RQ 3.0: What novel technologies and approaches can facilitate energy transitions and how can decision-support tools enable communities to envision alternative futures and make energy transition decisions while considering relevant social, technical, and biophysical impacts?

RQ 4.1: How does community participation in energy decisions shape energy transitions and community well-being?

RQ 4.2: What policies and management options, across which community and state scales, best empower community decision making and are most likely to facilitate renewable energy transitions?

RQ 4.3: How can we support communities in making choices that involve difficult tradeoffs between their own values and visions, and those of other communities, regions, and scales? 


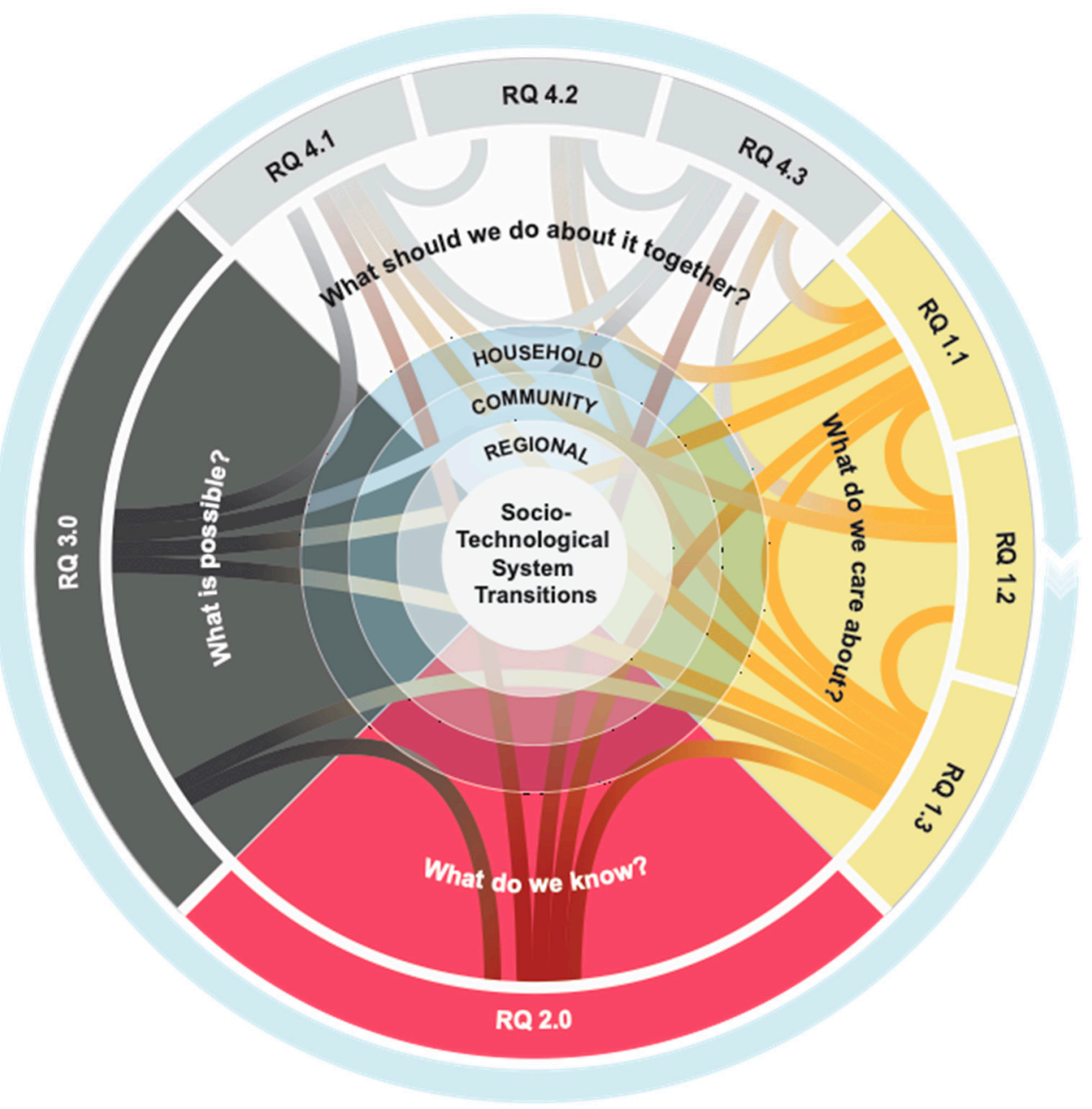

Figure 1. Socio-technological Systems Transitions Framework.

\section{Applying the Framework}

Applying this framework begins in the East (like the sunrise), with the question "What do we care about?". The framework is based on the proposition that, instead of starting by asking what is technically, economically, or politically possible, we instead start by asking about community cares, concerns, priorities, and values. The novelty of this approach is that it requires that technologies be situated within and that technological transitions be emergent from community priorities rather than starting with technical or economic considerations and then asking if they align with or contradict what a community actually cares about. A community's priorities may be situated, at least in part, within their existing socio-technological contexts. The novelty and value of beginning with a community-centered, rather than technologically or economically centered framework, involves understanding the ways in which current systems align with community values and the inability of existing systems to identify community challenges, future goals, and priorities.

\subsection{What Do We Care about?}

Renewable energy transitions are often framed in terms of the urgent need to address climate change and their immediate climate benefit. A plurality of individuals accept the fact of anthropogenic climate change, and with it, a shared responsibility to achieve carbon neutrality as quickly as possible. In this sense, the "We" in question is none other than humankind, and indeed, all life on earth. If the primary concern is GHG emissions, then a rapid transition using PV can meet the goal, even when considering life cycle carbon emissions [51]. PV development has increased efficiency for decades [52,53] across 
a wide range of PV materials, and each small increase in efficiency, using the same physical processes of production, not only reduced costs that increased the wide adoption of PV [54], but also the GHG emissions reduction potential of the technology has increased. In a conventional utility model, this would be done with utility-scale solar development and would technically meet that goal in the most economically efficient manner in a way that smaller systems could not [55]. Yet communities often care about the impacts of their electrical energy systems for reasons beyond GHG emissions. If they accept any responsibility at all, community actors may weigh a broad mandate to reduce emissions against specific ecological and economic concerns.

For communities who do share collective care for the environment or natural world, GHG emissions may be just one component of concern. Ecosystem integrity, habitat preservation, or species protection may also be community cares, and large, utility-scale solar systems may not align with these community priorities. In California, where there is a mandate to achieve zero-emission electricity production by 2045 , there have been protracted battles surrounding proposed utility-scale solar developments in the California Desert [56]. Though the state now requires rooftop solar to be a feature of all new construction [56], renewable industry advocates still anticipate that the state will fall far short of its goals unless it aggressively constructs utility-scale solar farms. Roughly $4000 \mathrm{MW}$ of solar sited on 30,000 acres has been proposed or is under construction. State modeling shows that California will need 90,000 to 125,000 more MW over the next 25 years [56]. Project permits have been contested by a coalition of tribal and environmental groups who argue that the development amounts to "a gigantic assault of these industrial projects on desert habitats and cultural sites", even though they favor California's carbon-neutral policy [56].

Similarly, Maryland has had difficulty siting utility-scale solar developments, despite a statewide goal of producing half its energy from carbon-neutral sources by 2030, with $14.5 \%$ of that coming from solar energy. A "responsible siting" task force convened by Gov. Larry Hogan concluded that up to $2.9 \%$ of prime farmland could be lost to solar development, even though the state has made strong efforts to preserve such land in the past [57].

As we see in these instances and many others, there is frequently an imbalance between the perceived economic and ecological burdens communities are asked to absorb for the sake of hosting utility-scale solar and that of the communities who would broadly benefit from lower utility costs and reduced carbon emissions. This can be true whether or not the energy produced by a project will be owned or purchased by a city or township's incumbent electricity provider. Utility-scale is cost-efficient precisely because it is concentrated, enabling one project to serve many households and businesses over a broad geographic area. Utility-scale solar benefits from scale in purchasing power for components, permitting, and even in labor, using all of the same equipment, but these benefits do not necessarily accrue to the host community.

In many cases, developers can design mid- to large-scale solar projects that maintain ecosystem functions, habitat access, and agricultural productivity [58,59]. A growing "agrivoltaic" movement to profitably co-site solar projects with livestock grazing and crop production has seen early promise [60]. Conventional PV farms can be intercropped with some agricultural products with no changes, and for other crops, developers can install solar panels with mounts tall enough for equipment and animals to pass under while justifying the increased expense with increased economic productivity of their land. Likewise, solar farms can host pollinator-friendly habitats that benefit agriculture and wildlife in the local areas.

Another approach to the application of solar that reduces conflict is floatovoltaics (FPV) [61-63], which is the deployment of floating PV onto water surfaces. Similar to agrivoltaics, FPV has a synergistic effect where the water cools the PV, thus reducing their operating temperature and improving the PV electrical conversion efficiency [64]. At the same time, the PV can reduce evaporation rates and thus improve water conservation [65]. FPV can be both on-grid and off-grid [66], as well as the base of microgrids [67], as in India. 
FPV can be deployed on a small scale in temporary summer-home systems [68], but also on a utility-scale in multi-MW permanent farms [69], as in the Seychelles. In perhaps the most efficient use of surface area, FPV and agrivoltaics can be combined to make aquavoltaics, where FPV are used in aquaculture. [70] Although there is enormous potential for FPV, even when artificially restricting deployment to human-made waterways [71], there are still obstacles to overcome, most of which are knowledge-based [72] (see Section 3.2 below).

As this framework demonstrates, starting with the question of what communities care about can reveal new areas for inquiry regarding the knowledge needed to meet a community's energy needs with available technology. In space-constrained environments or areas that culturally identify with agricultural land or waterways, these innovative technological applications may be particularly appropriate. Even with either agrivoltaics or FPV, in sensitive ecosystems or in areas with threatened species, the habitat impacts of solar may be undesirable in terms of alignment with community concerns. In this case, solar energy development through distributed generation may be desirable (i.e., rooftop installations and small ground mount systems). While these options may represent a more complicated process than utility-scale development, the alternative path honors varying and different community priorities. Given the nature of utility ratemaking, the costs of these projects will eventually be passed to ratepayers, some of whom may presumably object to funding anything beyond the most cost-efficient, large-scale development. Although, it should be pointed out that in many scenarios, because customer-owned PV often produces electricity costing less than the retail rates by enabling customers to invest in the systems, costs can be avoided for the utilities during a transition. Questions arise regarding who is included or excluded in the definitions of community and how differences across communities who share in the decision making and the consequences of energy system transitions are addressed. These considerations are further explored in the discussion below.

The primary cares regarding energy systems may include community control (including management, ownership, and sovereignty), economic concerns in which communities seek to prioritize energy transitions that reduce the cost of electricity access, or care for the environment. In communities that relate the direct application of energy to its end use, such as solar-heated water or electrically pumped groundwater used for bathing, cleaning, and agriculture, there is heightened "awareness of environmental rhythms" [73] (p. 9), creating increased efficiency and ingenuity, resulting in a more sustainable use of resources. In a report to the U.S. Department of Energy (DOE) published in 2008, the Saginaw Chippewa Tribe of southeastern Michigan presented "a vision to become self-sufficient in its energy needs and, in respect and concern for the next seven generations, to maintain its culture and protect Mother Earth", stating "sustainable green energy sources, such as solar, wind, and biomass energy, are the best energy paths to travel" [74] (p. 3). These communities reject what they view as the profit interests of privatized, corporate, fossil-fuel-dominant business models in favor of democratically-managed, publicly-owned RE systems that dismantle concentrated economic and political power. These systems serve the public good by reducing GHG emissions, creating local jobs, and providing equitable access to energy [75]. In these cases, technical or economic considerations become less salient than issues of ownership, decision making, resilience, and sovereignty [76]. Community energy sovereignty can be achieved through the integration of socioeconomic, political, and technological dimensions that link social justice and equity with energy innovation to democratize energy in support of autonomy, security, and resiliency [76]. Since 2008, the Saginaw Chippewa Tribe has developed physical energy infrastructure, including electrical substations, wind and solar generation, and power purchase agreements. On 30 October 2019, they established the Saginaw Chippewa Electric Authority to manage, operate, and maintain the electric distribution and generation system for their community [77].

For many communities, their primary concerns may not be directly related to energy at all. In low-income country contexts, consumers demonstrate more concern about the impact of their consumption than consumers in high-income country contexts, and are more likely to associate consumption habits with the degradation of personal and environmental 
health and take action to mitigate the effects [78]. In some low-income country contexts, a lack of adequate electricity energy provision through centralized distribution can motivate desires to learn more about solar energy as a decentralized and locally controlled option, particularly in the context of private sector actors who are motivated by financial considerations [79]. This transition framework suggests that learning about what communities care about-whether that be unsustainable consumption, equalizing access to economic wellbeing, decreasing the economic burdens of poverty or precarity in the community, increasing economic development opportunities, increasing jobs in the local community, protecting local or global environments, promoting community-level independence and resilience, increasing community amenities, reducing health impacts of fossil-fuel-driven air pollution, or any other community consideration-is the first and most important step in developing energy transition planning and decision making, which can succeed by aligning with community priorities.

\subsection{What Do We Know?}

When it comes to solar PV energy technology, there are several known and welldocumented technical, economic, and social advantages:

- PV are massive net energy producers: For some time now, PV modules have been shown to produce far more energy than is used to produce them [80]. PV efficiencies have steadily climbed [81], only driving the energy return over energy invested higher (with some PV "paying" their energy back in a year) [82].

- PV has "generational" long lifetimes and warranties: PV modules, in general, carry a warranty for $90 \%$ production at 10 years and $80 \%$ production at 25 years [83]. That means 25 years after the purchase of a solar panel, consumers can expect it to still be outputting $80 \%$ of its rated capacity. Many studies have shown that PV degradation rates are below $1 \% /$ year [84-89].

- $\quad$ PV has high reliability and durability in all environments where humans live: PV is reliable under the most extreme environmental conditions, from small losses due to snow in harsh Canadian winters [90] to scorching desert climates in Egypt [91].

- PV has low maintenance costs and no fuel costs: Solar PV systems do not require frequent inspection or maintenance [7] and require no fuels to operate (and thus no transport and storage of fuel either). This is a distinct benefit for communities globally without access to professional operations and maintenance (O\&M).

- $\quad$ PV reduces sound pollution: PV systems operate silently and with no movement (most systems) and minimal movement (single and dual-axis trackers).

- PV is extremely safe: PV systems do not require the use, transport, or storage of combustible fuels; they have no environmental emissions during use and are electrically safe when properly designed and installed. They also produce no nuclear waste.

- PV allows for flexible system architectures with grid-tied, decentralized generation, and grid independence: PV systems may operate independently of grid systems, but also can improve grid reliability with decentralized generation [92,93]. PV systems can be operated off-grid [94] and, when coupled with storage technologies and/or hybrid generation, can provide lower-cost power for those with poor electric infrastructure [95], as well as those in rural and low-income, previously colonized communities continuing to lack basic infrastructure.

- PV performance improves in cold and high altitudes: PV generation increases as the temperature drops [96,97], as well as at higher elevations (because of increased solar flux).

- $\quad$ PV systems are flexible and modular: Unlike conventional systems, PV modules may be added to photovoltaic systems to increase available power; they can be deployed almost anywhere the sun shines at scales appropriate for the situation. This is simply not possible with most conventional electric sources.

- PV can create jobs and enhance tax revenues: Currently, more than 250,000 Americans work in the solar industry $[98,99]$. Globally, the solar industry employs more than 
3.6 million people [100]. Depending on the tax regime, some governments that support solar see a return on investment (ROI) based on taxes; the Canadian government, for example, would earn a profit under any scenario supporting PV, including giving multi-million-dollar PV plants away for free [7].

- PV reduces the liability costs for conventional power plant operators: For the nuclear case, reduced potential liability from nuclear disasters [101-103] is so substantial that just displacing the nuclear insurance subsidy to solar would provide an additional $48,600 \mathrm{TWh}$ of electricity over nuclear worth $\$ 5.3$ trillion [104]. In fossil fuel cases, moving to solar would reduce carbon emission liability costs, which, similarly, could be worth hundreds of trillions of dollars [105].

- $\quad$ PV can enable low-income countries to leapfrog conventional centralized power plants and their concomitant problems: By encouraging the adoption of PV, rural areas in low-income and previously colonized country contexts, who have not built economies based on extractive exploitation of global economies, have particular promise to leapfrog conventional power sources, and the pollution and economic challenges they represent [106-108].

- The full values of solar (VOS) have shown numerous economic benefits [109-114]:

- Reduces conventional electricity market prices due to reduced peak demand

- Provides a valuable price hedge from using a free, renewable fuel rather than variably-priced fossil fuels

- Reduces costs due to avoiding new transmission and distribution infrastructure to manage electricity delivery from centralized power plants;

- Reduces need to build, operate, maintain, and buy fuel for fossil fuel-generating plants

- Reduces reserve capacity costs, distribution, and transmission costs

- Reduces electric outages due to a more reliable, distributed electric power system

- Reduces future costs of mitigating the environmental impacts of fossil fuel and nuclear generation

- Avoids health liability costs as well as saves lives (e.g., replacing all of coal-fired electricity with solar energy would save $~ 52,000$ American lives per year [115]).

The points above represent collective knowledge about solar. The distribution of these technical, economic, and social benefits, however, continue to be unknown, at least partially, because the distribution of benefits is shaped by diverse policy and regulatory regimes and a multitude of siting, investment, finance, and ownership choices that are made at the state, municipality, utility, and community levels. While the benefits may be undisputed, the matter of who receives these benefits, based on what specific kinds of choices shape development, is still an open question, representing factors unknown for communities to explore - and research illustrates that the distribution of these benefits is a primary concern shaping public support for solar energy development $[116,117]$.

Despite the numerous benefits, solar PV also has inevitable, as well as potentially negative impacts. There are real negative environmental consequences of PV production and disposal [118]. These negative impacts could be partially offset by recycling [94], and policies should encourage responsible industrial practices [119]. Solar PV is a capital asset and often consumers do not have access to capital, which reduces PV velocity and demands some form of financing [120-123] or securitization [124]. Life cycle assessments (LCA) performed on five common PV systems demonstrated that, while manufacturing and installation processes consume energy and generate some GHGs, the energy payback time (EPBT) for PV falls within the range of 0.7-3.5 years, with GHG emission rates an order of magnitude smaller than those of fossil-based electricity [125].

Because solar is an intermittent resource, it must be coupled with other renewable energy sources like hydro or wind, as well as storage, to completely offset all conventional generation. Intermittency can be reduced and accommodated by interconnecting intermittent resources, forecasting their variation, and integrating them with dispatchable renewable sources (such as hydropower, geothermal, and biomass). Demand response 
(or demand-side management), can shift flexible loads in order to optimize intermittent production. With the growth in demand, electrical energy storage (EES) and power balancing technologies are rapidly developing, with year-on-year growth of EES in emerging markets expected to reach $40 \%$ through 2025 [126]. Various means of EES can be utilized for frequency regulation, flexible ramping, black start services, and to reduce curtailment of variable renewable energy production $[127,128]$.

Regulations are evolving as well, for example, the U.S. Federal Energy Regulatory Commission (FERC) FERC Order No. 2222, approved in 2020, creates pathways for storage and distributed energy resources (DERs) to participate in wholesale markets serviced by regional transmission operators or independent system operators (RTOs/ISOs) by establishing distributed energy resources (DERs) as a market participant category and allowing them to aggregate in order to satisfy minimum size and performance requirements [129]. It is necessary to develop both these technologies and the enabling regulations that support their deployment at a pace adequate to fully leverage solar energy's potential contribution to collective electrical energy needs.

The points above address what is known technically and economically about solar energy technology. There is, however, another way to address the question posed above about what is collectively known. Individuals and communities know things through their lived experience, through their traditions and cultures, and through intergenerational ontologies, knowledge systems passed down through generations representing collective understandings of reality.

Some communities, including within the United States, hold different understandings of technologies and the willingness to accept their potential impacts. For example, consider the viewpoint of a community regarding the impact of a PV system on a particular wild animal whose habitat may need to be drained to install a solar farm. For Indigenous Nations communities in the United States and throughout the world, the collectively held understanding of reality may involve extended understandings of kinship, relationality, and responsibility [130]. As just one example, there are multiple possible perspectives for understanding the nature of the beaver-is this animal a pest who creates damage to waterways, or is it a relative, demonstrating to the world the building capacity of making homes in ways that are synergistically beneficial for other species and entire ecologies? The answer depends on ontology [131], which can vary across communities as well as across time and place. There are different ways to answer the question about what is known regarding how humans live and relate to the rest of the world, and the answer to these questions will shape how communities make decisions regarding energy development. In this example, understanding animals as relatives changes whether or not it is acceptable to relocate individual animals or damage the habitat of species to pursue rapid utility-scale solar development. Similarly, whether a community knows that their utility company is trustworthy, their trees are sacred, or myriad other knowledge objects or systems, will shape priorities and possibilities for community-supported solar development.

\subsection{What Is Possible?}

Answering the question "What is possible?" depends on the answers to the questions above, but also depends on the utility, regulatory, and policy context, as well as the economic and technical context of any given community. What is possible depends on a community's willingness to invest, environmental factors such as land availability or shading, the quality of local infrastructure, roof engineering, access to capital and financing, local regulations, state and federal regulations and incentives, and a multitude of other economic, technical, and regulatory factors. Some of these conditions of possibility may be in the community's power to change, while others may not. A community might choose to look at available options given current incentives and regulatory regimes. On the other hand, they may decide to advocate for changes to the regulatory regimes in which they are situated, in a way that better aligns with their goals and values. 
One way to address this question focuses on what is possible in the current regulatory regime. Given the need for power purchase agreements (PPAs) to ensure that generated solar energy can be integrated into the grid and compensated at a fair market price, utility structures must have existing options for PPAs for community investment in solar energy to make sense. In the United States, some IOUs create barriers to integrating solar into the grid [132], even if there is a community willing to host and a willing financial investor. For large scale solar, what is possible may also depend on policy beyond energy policy, as land access, zoning issues, and policy regarding the use and taxation of agricultural land can all shape whether or not solar development is possible.

Where they have siting jurisdiction, counties and townships have an opportunity to proactively plan if and how they would allow utility-scale renewable development into their communities [133]. Local governments can use the planning and zoning process to create height restrictions, setbacks, and land use requirements that either signal to developers they are cleared for approach, or that utility-scale projects are unwelcome. Agricultural policy is often restrictive and limiting for solar development. As described above, there is a concern about PV farms offsetting food production when sited in agricultural communities [134]. This can be partially ameliorated by careful planning and through agrivoltaics (the co-location of PV and conventional crops) $[135,136]$. When they are open to development, municipalities may include ordinance language, encouraging or requiring pollinator-friendly habitats and other agrivoltaic features [133]. Municipalities that own their own electric utilities and would like to build medium- or large-scale renewable energy projects can include such parameters in development.

The operation of the current U.S. federal economic incentive as a tax credit also limits the possibilities for entities without a tax appetite, as one must have significant tax liabilities in order to take advantage of these credits [137]. Municipalities and other non-profit entities cannot benefit financially from a tax incentive for solar investment. In the U.S., municipalities are limited in the extent to which they are allowed to accrue debt, hindering their ability to make public investments in solar energy development. Limited public investment in solar encourages development by private corporate actors, who may try to co-opt new innovation in order to stymy market disruptions those innovations may create, and reinject capital into incumbent systems. This may slow the pace of clean energy transitions, and also acts to suppress technological innovation, and undermine opportunities for democratic control of energy resources [138]. Municipal, community, and cooperatively owned and controlled energy producers have the agility to prioritize energy security, energy democracy, and community development, as they are not beholden to generate profits for shareholders [139] but are instead accountable to citizens and their members, respectively.

Addressing the conditions of possibility may also require collective organization to change the incumbent electrical energy regimes. These regimes have resisted transitions to renewable energy, citing economic and technical difficulties. However, it is perceived that the more plausible motivation is the preservation of profits from existing business models, regulatory frameworks, and subsidies. Incumbent regimes have formed coalitions with politicians and think tanks to undermine climate science and resist renewable energy transitions [140], including reforms in utility structure, as well as policy and regulatory structures that shape solar energy technology development. Some of the ways a community may influence the existing regime require investments, including economic investments in publicly-owned solar. Due to the political and market power of incumbent regimes, existing business models, and regulatory frameworks, this investment requires government intervention [141]. In the U.S., this could take place through initiatives that would be supported by the passing of House Resolution 109, 2019-20, also known as the Green New Deal [142]. Communities must also invest time and knowledge to advocate for policy change. Some of the policies that can be changed to improve the conditions of possibility for solar energy development include subsidy reforms [143], eliminating solar rooftop bans in homeowner's associations, caps on carbon production, eliminating regulatory obstacles 
to grid integration of solar and related technology, eliminating caps on grid-integrated solar [132], improving the transparency and financial benefits associated with net metering and feed-in tariff programs [144], improving and utilizing energy efficiency programs to lessen energy demand and the associated economic and environmental impacts, and advocating or organizing for an increase in public utility ownership [145].

\subsection{What Should We Do about It Together?}

In short, the answer to this question depends on the answers to the questions that precede it. This, we argue, is the value of this framework. Instead of starting with an externally identified objective (such as increasing renewable energy or solar energy deployment), this framework begins by centering and empirically examining community concerns, values, and priorities. It also requires addressing empirically the conditions and state of knowledge, both knowledge of technologies and the knowledge collectively held and known to be true by communities [146]. Both community concerns and community knowledge will shape the conditions of possibility for energy transitions; asking about these conditions of possibility also reveals the myriad economic, technical, structural, and regulatory factors that determine what is possible for communities. Researchers can best support energy democracy and energy sovereignty in community scale energy transitions by using these questions to inform proposals for what should be collectively done to support energy transitions that align with community preferences.

\section{Discussion}

The application of this framework reveals several conceptual and empirical tensions. The first is the very nature and definition of community in community energy transitions research. Communities are never perfectly homogenous, and capturing the diversity of community perspectives, including tensions or divergence within a community, is also key to understanding a community's perspective; this framework is focused on finding generally shared understandings, but application should not ignore differences or contradictions, as they can also help inform community decision making. Also, how a community is defined may depend on already existing dynamics of inclusion and exclusion that researchers should not ignore; intentionally attending to such dynamics is key for valid empirical research.

Furthermore, the nature of community in energy research is inevitably complex, as energy systems may be developed in communities that do not benefit financially or otherwise from that development. While utility territories (the geographical space where a utility is given a monopoly to operate) represent a simplified way to define community, utilities may invest in renewable energy systems sited outside their territory, and communities may self-identify in ways that are not at all based on utility providers. Attending to this complexity is an essential component of applying the framework proposed above.

\section{Conclusions}

This paper explored how a proposed framework for understanding socio-technological system transitions can be applied to solar photovoltaic energy technology development to reveal the complex web of factors involved in solar energy decision making. By starting with what a community cares about, choices regarding the scale, siting, and ownership of solar energy development can be informed by community priorities. By asking what is collectively known, both about a technology and by a community, the framework can be used to reveal gaps in knowledge, as well as culturally diverse ways of knowing that will shape community values and decision making. Answering the question about what is possible requires addressing both community cares and knowledge. It also requires unpacking the complexity of factors that shape conditions of possibility-factors such as existing utility structures and federal, state, and local energy policies, regulation, and incentives, but also factors such as agricultural policy and land zoning as well as land availability, roof engineering, municipal debt burdens, and the various forms of capital, including 
economic as well as knowledge and temporal capital that will shape a community's ability to navigate existing regimes, or challenge and change them.

The advantages of solar energy are potentially wide-ranging, including environmental, economic, technological, distributional, and social impacts associated with justice and equity; yet, these benefits are widely dependent on how PV development takes place, including not only siting and scale considerations, but also ownership, participation, and other social factors. The limitations of PV, including the need for land access, the complexities of ownership and distribution, and the demand for energy storage for balancing production and consumption, can all arguably be addressed more effectively by using a decision-making framework that centers community values, social priorities, and participatory processes. There is an urgent need to adopt frameworks, such as the one described above, to correct the harm caused by the use of previous models in development contexts, and to build social learning and social engagement into the processes of PV development.

Solar energy technology has enormous potential. Its flexibility is an enormous asset for being able to deploy solar in ways that align with community priorities and values. By centering communities rather than technologies, the framework proposed here can encourage energy transitions that have community support because they align with community priorities. Applying this framework to solar energy technology reveals the vast potential of this technology as well as this framework, but also reveals the challenges and potential hurdles that could shape successful deployment. Addressing these challenges to rapidly promote solar energy technology development that enhances energy sovereignty and community wellbeing is essential for addressing the catastrophic consequences of the global climate crisis being caused by the use of fossil fuels, and for promoting the social justice consequences of a democratized energy system.

Author Contributions: Conceptualization, C.S.; investigation, J.M.P., D.L., E.M.; data curation, J.M.P., D.L., E.M.; writing—original draft preparation, C.S., J.M.P., D.L.; E.M.; writing—review and editing, D.L., C.S., J.M.P., E.M.; project administration, C.S.; All authors have read and agreed to the published version of the manuscript.

Funding: Funding for this work has been provided to a large, transdisciplinary research team through the National Science Foundation Convergence program, on a project titled "GCR: Michigan Community \& Anishinaabe Renewable Energy Sovereignty [MICARES]," award \#1934346.

Data Availability Statement: Data sharing not applicable.

Acknowledgments: The authors would like to thank the entire MICARES teams and our community collaborations.

Conflicts of Interest: The authors declare no conflict of interest. The funders had no role in the design of the study; in the collection, analyses, or interpretation of data; in the writing of the manuscript, or in the decision to publish the results.

\section{References}

1. Yu, C.F.; van Sark, W.G.J.H.M.; Alsema, E.A. Unraveling the photovoltaic technology learning curve by incorporation of input price changes and scale effects. Renew. Sustain. Energy Rev. 2011, 15, 324-337. [CrossRef]

2. Hong, S.; Chung, Y.; Woo, C. Scenario analysis for estimating the learning rate of photovoltaic power generation based on learning curve theory in South Korea. Energy 2015, 79, 80-89. [CrossRef]

3. Mauleón, I. Photovoltaic learning rate estimation: Issues and implications. Renew. Sustain. Energy Rev. 2016, 65, 507-524. [CrossRef]

4. Feldman, D.; Barbose, G.; Margolis, R.; Wiser, R.; Darghouth, N.; Goodrich, A. Photovoltaic (PV) Pricing Trends: Historical, Recent, and Near-Term Projections; National Renewable Energy Laboratory: Golden, CO, USA, 2012.

5. $\quad$ Barbose, G.L.; Darghouth, N.R.; Millstein, D.; LaCommare, K.H.; DiSanti, N.; Widiss, R. Tracking the Sun X: The Installed Price of Residential and Non-Residential Photovoltaic Systems in the United States; Lawrence Berkley National Laboratory: Berkeley, CA, USA, 2017.

6. Reuters. Solar Costs to Fall Further, Powering Global Demand-Irena. 2017. Available online: https://www.reuters.com/article/ singapore-energy-solar-idUSL4N1MY2F8 (accessed on 7 April 2020).

7. Branker, K.; Pathak, M.J.M.; Pearce, J.M. A review of solar photovoltaic levelized cost of electricity. Renew. Sustain. Energy Rev. 2011, 15, 4470-4482. [CrossRef] 
8. Lai, C.S.; McCulloch, M.D. Levelized cost of electricity for solar photovoltaic and electrical energy storage. Appl. Energy 2017, 190, 191-203. [CrossRef]

9. Kang, M.H.; Rohatgi, A. Quantitative analysis of the levelized cost of electricity of commercial scale photovoltaics systems in the US. Sol. Energy Mater. Sol. Cells 2016, 154, 71-77. [CrossRef]

10. Richard, C. New Wind and Solar Cheaper Than Existing Coal and Gas. 2018. Available online: http:/ /www.windpowermonthly. com/article/1491146?utm_source=website\&utm_medium=social (accessed on 7 April 2020).

11. IRENA. Renewable Power Generation Costs in 2017; IRENA: Abu Dhabi, United Arab Emirates, 2018.

12. Dudley, D. Renewable Energy Will Be Consistently Cheaper Than Fossil Fuels By 2020, Report Claims. Forbes 2018. Available online: https:/ / www.forbes.com/sites/dominicdudley/2018/01/13/renewable-energy-cost-effective-fossil-fuels-2020/ (accessed on 7 April 2020).

13. Kroll, M.; Otto, M.; Käsebier, T.; Füchsel, K.; Wehrspohn, R.; Kley, E.B.; Tünnermann, A.; Pertsch, T. Black silicon for solar cell applications. In Photonics for Solar Energy Systems IV; International Society for Optics and Photonics: Brussels, Belgium, 2012; Volume 8438. [CrossRef]

14. Modanese, C.; Laine, H.; Pasanen, T.; Savin, H.; Pearce, J. Economic Advantages of Dry-Etched Black Silicon in Passivated Emitter Rear Cell (PERC) Photovoltaic Manufacturing. Energies 2018, 11, 2337. [CrossRef]

15. Liang, T.S.; Pravettoni, M.; Deline, C.; Stein, J.S.; Kopecek, R.; Singh, J.P.; Luo, W.; Wang, Y.; Aberle, A.G.; Khoo, Y.S. A review of crystalline silicon bifacial photovoltaic performance characterisation and simulation. Energy Environ. Sci. 2019, 12, 116-148. [CrossRef]

16. Burnham, L.; Riley, D.; Walker, B.; Pearce, J.M. Performance of bifacial photovoltaic modules on a dual-axis tracker in a highlatitude, high-albedo environment. In Proceedings of the 2019 IEEE 46th Photovoltaic Specialists Conference (PVSC), Chicago, IL, USA, 16 June 2019; pp. 1320-1327.

17. Barron, A. Cost reduction in the solar industry. Mater. Today 2015, 18, 2-3. [CrossRef]

18. Center for Climate and Energy Solutions (CECS). Renewable Energy. 2019. Available online: https://www.c2es.org/content/ renewable-energy/ (accessed on 11 November 2020).

19. IEA. Snapshot of Global PV Markets 2020 Report IEA-PVPS T1-37. 2020. Available online: https://iea-pvps.org/wp-content/ uploads/2020/04/IEA_PVPS_Snapshot_2020.pdf (accessed on 11 November 2020).

20. PEW Research Center. Available online: https://www.pewresearch.org/science/wp-content/uploads/sites/16/2019/11 /Climate-Energy-REPORT-11-22-19-FINAL-for-web-1.pdf (accessed on 31 December 2020).

21. Gerbinet, S.; Belboom, S.; Léonard, A. Life Cycle Analysis (LCA) of photovoltaic panels: A review. Renew. Sustain. Energy Rev. 2014, 38, 747-753. [CrossRef]

22. Metcalfe, M. Grid Efficiency: An Opportunity to Reduce Emissions. 2020. Available online: https://energycentral.com/c/ec/ grid-efficiency-opportunity-reduce-emissions (accessed on 9 November 2020).

23. US Energy Information Administration (EIA). More Than $60 \%$ of Energy Used for Electricity Generation Is Lost in Conversion. 2020. Available online: https:/ / www.eia.gov/todayinenergy/detail.php?id=44436 (accessed on 11 November 2020).

24. Surana, K.; Jordaan, S.M. The climate mitigation opportunity behind global power transmission and distribution. Nat. Clim. Chang. 2019, 9, 660-665. [CrossRef]

25. Banerjee, B.; Islam, S.M. Reliability based optimum location of distributed generation. Int. J. Electr. Power Energy Syst. 2011, 33, 1470-1478. [CrossRef]

26. Liu, L.; Bao, H.; Liu, H. Siting and sizing of distributed generation based on the minimum transmission losses cost. In Proceedings of the 2011 IEEE Power Engineering and Automation Conference, Wuhan, China, 8-9 September 2011; Volume 3, pp. 22-25. [CrossRef]

27. Barker, P.P.; De Mello, R.W. Determining the impact of distributed generation on power systems. I. Radial distribution systems. In Proceedings of the 2000 Power Engineering Society Summer Meeting (Cat. No.00CH37134), Seattle, WA, USA, 16-20 July 2000; Volume 3, pp. 1645-1656. [CrossRef]

28. Saad, N.M.; Sujod, M.Z.; Lee, H.M.; Abas, M.F.; Jadin, M.S.; Ishak, M.R.; Abdullah, N.R. Impacts of Photovoltaic Distributed Generation Location and Size on Distribution Power System Network. Int. J. Power Electron. Drive Syst. 2018, 9, 905. [CrossRef]

29. Energy Information Administration. Available online: https://www.eia.gov/tools / faqs / faq.php?id=97\&t=3 (accessed on 31 December 2020).

30. Pearce, J.M. Photovoltaics-A path to sustainable futures. Futures 2002, 34, 663-674. [CrossRef]

31. Krishnan, R.; Haselhuhn, A.; Pearce, J.M. Technical solar photovoltaic potential of scaled parking lot canopies: A case study of walmart USA. J. Innov. Sustain. RISUS 2017, 8, 104-125. [CrossRef]

32. Denholm, P.; Margolis, R.M. Land-use requirements and the per-capita solar footprint for photovoltaic generation in the United States. Energy Policy 2008, 36, 3531-3543. [CrossRef]

33. Wüstenhagen, R.; Wolsink, M.; Bürer, M.J. Social acceptance of renewable energy innovation: An introduction to the concept. Energy Policy 2007, 35, 2683-2691. [CrossRef]

34. Sovacool, B. Exploring and Contextualizing Public Opposition to Renewable Electricity in the United States. Sustainability 2009, 1, 702-721. [CrossRef]

35. Sovacool, B.K.; Ratan, P.L. Conceptualizing the acceptance of wind and solar electricity. Renew. Sustain. Energy Rev. 2012, 16, 5268-5279. [CrossRef] 
36. Batel, S.; Devine-Wright, P.; Tangeland, T. Social acceptance of low carbon energy and associated infrastructures: A critical discussion. Energy Policy 2013, 58, 1-5. [CrossRef]

37. Calvert, K.; Mabee, W. More solar farms or more bioenergy crops? Mapping and assessing potential land-use conflicts among renewable energy technologies in eastern Ontario, Canada. Appl. Geogr. 2015, 56, 209-221. [CrossRef]

38. Calvert, K.; Pearce, J.M.; Mabee, W.E. Toward renewable energy geo-information infrastructures: Applications of GIScience and remote sensing that build institutional capacity. Renew. Sustain. Energy Rev. 2013, 18, 416-429. [CrossRef]

39. Ricketts, S.; Cliffton, R.; Oduyeru, L.; Holland, B. States Are Laying a Road Map for Climate Leadership. 2020. Available online: https:/ / www.americanprogress.org/issues/green/reports/2020/04/30/484163/states-laying-road-map-climateleadership / (accessed on 18 November 2020).

40. Ryser, J. Midwest Utilities Craft Ambitious Renewables, Coal-Retirement Plans to Meet Goals. 2020. Available online: https: / / www.spglobal.com/platts/en/market-insights/latest-news/electric-power/110920-midwest-utilities-craft-ambitiousrenewables-coal-retirement-plans-to-meet-goals (accessed on 18 November 2020).

41. Marcacci, S. Solar Brightfields: Gigawatts Of Clean Energy Potential On America's Landfills and Brownfields. 2017. Available online: https:/ / www.forbes.com/sites/energyinnovation/2017/08/10/solar-brightfields-gigawatts-of-clean-energy-potentialon-americas-landfills-and-brownfields / (accessed on 8 October 2020).

42. Nye, D.E. Consuming Power: A Social History of American Energies; MIT Press: Cambridge, MA, USA, 1999.

43. Geels, F.W. Disruption and low-carbon system transformation: Progress and new challenges in socio-technical transitions research and the Multi-Level perspective. Energy Res. Soc. Sci. 2018, 37, 224-231. [CrossRef]

44. Geels, F.W.; Schot, J. Typology of sociotechnical transition pathways. Res. Policy 2007, 36, 399-417. [CrossRef]

45. Geels, F.W. Regime Resistance against Low-Carbon Transitions: Introducing Politics and Power into the Multi-Level Perspective. Theory Cult. Soc. 2014, 31, 21-40. [CrossRef]

46. Geels, F.W. From sectoral systems of innovation to socio-technical systems: Insights about dynamics and change from sociology and institutional theory. Res. Policy 2004, 33, 897-920. [CrossRef]

47. Adesanya, A.; Sidortsov, R.V.; Schelly, C. Act locally, transition globally: Grassroots resilience, local politics, and five municipalities in the United States with 100\% renewable electricity. Energy Res. Soc. Sci. 2020, 67, 101579. [CrossRef]

48. Christensen, C. The Innovator's Dilemma: When New Technologies Cause Great Firms to Fail; Harvard Business School Press: Boston, MA, USA, 1997.

49. Osunmuyiwa, O.; Biermann, F.; Kalfagianni, A. Applying the multi-level perspective on socio-technical transitions to rentier states: The case of renewable energy transitions in Nigeria. J. Environ. Policy Plan. 2018, 20, 143-156. [CrossRef]

50. Bessette, D.; Schelly, C.; Schmitt Olabisi, L.; Gagnon, V.; Fiss, A.; Arola, K.; Matz, E.; Ong, R.; Halvorsen, K. Energy democracy in practice: Centering energy sovereignty in rural communities and Tribal Nations. In Routledge Handbook of Energy Democracy; Feldpausch-Parker, A., Endres, D., Peterson, T.R., Gomez, S., Eds.; Under Contract with Routledge Press: Abingdon, UK, 2021.

51. Kenny, R.; Law, C.; Pearce, J.M. Towards real energy economics: Energy policy driven by life-cycle carbon emission. Energy Policy 2010, 38, 1969-1978. [CrossRef]

52. Green, M.A. Tracking solar cell conversion efficiency. Nat. Rev. Phys. 2020, 2, 172-173. [CrossRef]

53. Green, M.A.; Dunlop, E.D.; Hohl-Ebinger, J.; Yoshita, M.; Kopidakis, N.; Hao, X. Solar cell efficiency tables (version 56). Prog. Photovolt. Res. Appl. 2020, 28, 629-638. [CrossRef]

54. Solar Reviews. Available online: https://www.solarreviews.com/blog/where-is-solar-power-used-the-most (accessed on 31 December 2020).

55. Alan, G.; James, T.; Woodhouse, M. Residential, Commercial, and Utility-Scale Photovoltaic (PV) System Prices in the United States: Current Drivers and Cost-Reduction Opportunities; No. NREL/TP-6A20-53347; National Renewable Energy Lab. (NREL): Golden, CO, USA, 2012.

56. Wilson, J. Solar Surges in the California Desert So Why Are Environmentalists Upset? 2020. Available online: https://www. desertsun.com/story/news/environment/2020/01/03/solar-surges-california-desert-environment-trump/2665799001/ (accessed on 19 November 2020).

57. Wheeler, T.B. Maryland Climate Goals Threatened Over Friction Over Solar Projects. 2020. Available online: https: / / www.delmarvanow.com/story / news/local/maryland/2020/11/07/maryland-climate-goals-threatened-friction-oversolar-projects / 6163140002/ (accessed on 19 November 2020).

58. Dinesh, H.; Pearce, J.M. The potential of agrivoltaic systems. Renew. Sustain. Energy Rev. 2016, 54, 299-308. [CrossRef]

59. Dupraz, C.; Marrou, H.; Talbot, G.; Dufour, L.; Nogier, A.; Ferard, Y. Combining solar photovoltaic panels and food crops for optimising land use: Towards new agrivoltaic schemes. Renew. Energy 2011, 36, 2725-2732. [CrossRef]

60. Charles, D. How to Have Your Solar Farm and Keep Your Regular Farm Too. 2020. Available online: https:/ / www.npr.org/2020 /10/09/919225272/how-to-have-your-solar-farm-and-keep-your-regular-farm-too (accessed on 19 November 2020).

61. Kumar, N.M.; Kanchikere, J.; Mallikarjun, P. Floatovoltaics: Towards improved energy efficiency, land and water management. Int. J. Civ. Eng. Technol. 2018, 9, 1089-1096.

62. Dhas, T.R. A Review on New Era of Solar Power Systems: Floatovoltaic Systems or Floating Solar Power Plants. Manag. J. Instrum. Control Eng. 2014, 3, 1.

63. Gorjian, S.; Sharon, H.; Ebadi, H.; Kant, K.; Scavo, F.B.; Tina, G.M. Recent technical advancements, economics and environmental impacts of floating photovoltaic solar energy conversion systems. J. Clean. Prod. 2020, 278, 124285. [CrossRef] 
64. Aznar, A. Exploring Floatovoltaics: How Floating Solar PV Could Influence Our Changing Energy Landscape; National Renewable Energy Lab. (NREL): Golden, CO, USA, 2018.

65. Hayibo, K.S.; Mayville, P.; Kailey, R.K.; Pearce, J.M. Water Conservation Potential of Self-Funded Foam-Based Flexible SurfaceMounted Floatovoltaics. Energies 2020, 13, 6285. [CrossRef]

66. Campana, P.E.; Wästhage, L.; Nookuea, W.; Tan, Y.; Yan, J. Optimization and assessment of floating and floating-tracking PV systems integrated in on-and off-grid hybrid energy systems. Sol. Energy 2019, 177, 782-795. [CrossRef]

67. Kaushik, D.; Pooja, J. Floatovoltaic microgrids: New possibilities of decentralizing water-energy sector in India. Int. J. Res. Appl. Sci. Eng. Technol. 2020, 8, 1916-1922.

68. Mayville, P.; Patil, N.V.; Pearce, J.M. Distributed manufacturing of after market flexible floating photovoltaic modules. Sustain Energy Technol. Assess. 2020, 42, 100830. [CrossRef]

69. Renewable Energy World. Available online: https://www.renewableenergyworld.com/2020/04/07/seychelles-to-build-worldslargest-floating-solar-plant/ (accessed on 31 December 2020).

70. Pringle, A.M.; Handler, R.M.; Pearce, J.M. Aquavoltaics: Synergies for dual use of water area for solar photovoltaic electricity generation and aquaculture. Renew. Sustain. Energy Rev. 2017, 80, 572-584. [CrossRef]

71. Spencer, R.S.; Macknick, J.; Aznar, A.; Warren, A.; Reese, M.O. Floating photovoltaic systems: Assessing the technical potential of photovoltaic systems on man-made water bodies in the continental United States. Environ. Sci. Technol. 2018, 53, 1680-1689. [CrossRef] [PubMed]

72. Armstrong, A.; Page, T.; Thackeray, S.J.; Hernandez, R.R.; Jones, I.D. Integrating environmental understanding into freshwater floatovoltaic deployment using an effects hierarchy and decision trees. Environ. Res. Lett. 2020, 15, 114055. [CrossRef]

73. Buechler, S.; Vázquez-García, V.; Martínez-Molina, K.G.; Sosa-Capistrán, D.M. Patriarchy and (electric) power? A feminist political ecology of solar energy use in Mexico and the United States. Energy Res. Soc. Sci. 2020, 70, 101743. [CrossRef]

74. Tribe, P. Renewable Energy Opportunities Saginaw Chippewa Indian Tribe; Rep. No. DE-FG36-04GO14252; AOOO: Saginaw, MI, USA, 2008; p. 3.

75. Burke, M.; Stephens, J. Political power and renewable energy futures: A critical review. Energy Res. Soc. Sci. 2018, 35, 78-93. [CrossRef]

76. Schelly, C.; Bessette, D.; Brosemer, K.; Gagnon, V.; Arola, K.L.; Fiss, A.; Pearce, J.M.; Halvorsen, K.E. Energy policy for energy sovereignty: Can policy tools enhance energy sovereignty? Sol. Energy 2020, 205, 109-112. [CrossRef]

77. Saginaw Chippewa Tribal Law, Ordinance No. 35 Electricity Authority. 2019. Available online: http://www.sagchip.org/ tribalcourt/ordinance/Ordinance\%2035\%20Electric\%20Authority.pdf (accessed on 12 January 2021).

78. Pontoni, F.; Bruschi, I. Sustainable consumption: A multi-level perspective of a systematic transition. In Inclusive and Sustainable Industrial Development Working Paper Series_WP 16; United Nations Industrial Development Organization: Vienna, Austria, 2018. Available online: https:/ / www.unido.org/api/opentext/documents/download/10378550/unido-file-10378550 (accessed on 12 January 2021).

79. Adesanya, A.A.; Schelly, C. Solar PV-Diesel Hybrid Systems for the Nigerian Private Sector: An Impact Assessment. Energy Policy 2019, 132, 196-207. [CrossRef]

80. Pearce, J.; Lau, A. Net Energy Analysis For Sustainable Energy Production From Silicon Based Solar Cells. In Proceedings of the American Society of Mechanical Engineers Solar 2002: Sunrise on the Reliable Energy Economy, Reno, NV, USA, 15-20 June 2002; Cambell-Howe, R., Ed.; American Society of Mechanical Engineers: New York, NY, USA, 2002.

81. NREL. Best Research-Cell Efficiency Chart. Available online: https://www.nrel.gov/pv/cell-efficiency.html (accessed on 12 January 2021).

82. Bhandari, K.P.; Collier, J.M.; Ellingson, R.J.; Apul, D.S. Energy payback time (EPBT) and energy return on energy invested (EROI) of solar photovoltaic systems: A systematic review and meta-analysis. Renew. Sustain. Energy Rev. 2015, 47, 133-141. [CrossRef]

83. Available online: https://news.energysage.com/shopping-solar-panels-pay-attention-to-solar-panels-warranty/ (accessed on 31 December 2020).

84. Skoczek, A.; Sample, T.; Dunlop, E.D. The Results of Performance Measurements of Field-aged Crystalline Silicon Photovoltaic Modules. Prog. Photovolt. Res. Appl. 2009, 17, 227-240. [CrossRef]

85. Realini, A. Mean Time before Failure of Photovoltaic Modules; Final Report (MTBF Project) BBW 99.0579; Federal Office for Education and Science: Berne, Germany, 2003. Available online: http:/ /intigaia.free.fr/BDPV/Documents/rapporto $\% 20$ finale $\% 20-\% 20$ progetto $\% 20 \mathrm{eu} \% 205 \mathrm{fp} \% 20-\% 20$ mean $\% 20$ time $\% 20$ before $\% 20$ failure $\% 20$ (mtbf) \%202003.pdf (accessed on 12 January 2021).

86. Holladay, M. Testing a Thirty-Year-Old Photovoltaic Module-It's Time to Hook up Myoldest Solar Panel to a Multimeter. Green Building Advisor.com. 2010. Available online: https:/ / www.greenbuildingadvisor.com/article/testing-a-thirty-year-oldphotovoltaic-module (accessed on 12 January 2021).

87. Dunlop, E.D.; Halton, D.; Ossenbrink, H.A. 20 years of life and more: Where is the end of life of a PV module? In Proceedings of the Conference Record of the Thirty-First IEEE Photovoltaic Specialists Conference, Lake Buena Vista, FL, USA, 3-7 January 2005; pp. 1593-1596.

88. Jordan, D.C.; Kurtz, S.R. Reliability and Geographic Trends of 50,000 Photovoltaic Systems in the USA; National Renewable Energy Laboratory: Amsterdam, The Netherlands, 2014; p. 10.

89. Phinikarides, A.; Kindyni, N.; Makrides, G.; Georghiou, G.E. Review of photovoltaic degradation rate methodologies. Renew. Sustain. Energy Rev. 2014, 40, 143-152. [CrossRef] 
90. Andrews, R.W.; Pollard, A.; Pearce, J.M. The effects of snowfall on solar photovoltaic performance. Sol. Energy 2013, 92, 84-97. [CrossRef]

91. El-Rafey, E.; El-Sherbiny, M. Load/weather/insolation database for estimating photovoltaic array and system performance in Egypt. Sol. Energy 1988, 41, 531-542. [CrossRef]

92. Yuan, G. Improving grid reliability through integration of distributed PV and energy storage. In Proceedings of the 2012 IEEE PES Innovative Smart Grid Technologies (ISGT), Washington, DC, USA, 16-20 January 2012.

93. Koh, L.H.; Peng, W.; Tseng, K.J.; ZhiYong, G. Reliability evaluation of electric power systems with solar photovoltaic \& energy storage. In Proceedings of the 2014 International Conference on Probabilistic Methods Applied to Power Systems (PMAPS), Durham, UK, 7-10 July 2014; pp. 1-5.

94. Mohanty, P.; Muneer, T.; Kolhe, M. (Eds.) Solar Photovoltaic System Applications: A Guidebook for Off-Grid Electrification; Springer: Berlin/Heidelberg, Germany, 2015.

95. Adesanya, A.A.; Pearce, J.M. Economic viability of captive off-grid solar photovoltaic and diesel hybrid energy systems for the Nigerian private sector. Renew. Sustain. Energy Rev. 2019, 114, 109348. [CrossRef]

96. Siecker, J.; Kusakana, K.; Numbi, B.P. A review of solar photovoltaic systems cooling technologies. Renew. Sustain. Energy Rev. 2017, 79, 192-203. [CrossRef]

97. Dubey, S.; Sarvaiya, J.N.; Seshadri, B. Temperature dependent photovoltaic (PV) efficiency and its effect on PV production in the world-A review. Energy Procedia 2013, 33, 311-321. [CrossRef]

98. Louie, E.P.; Pearce, J.M. Retraining investment for US transition from coal to solar photovoltaic employment. Energy Econ. 2016, 57, 295-302. [CrossRef]

99. Pai, S.; Zerriffi, H.; Jewell, J.; Pathak, J. Solar has greater techno-economic resource suitability than wind for replacing coal mining jobs. Environ. Res. Lett. 2020, 15, 034065. [CrossRef]

100. Available online: https:/ / www.statista.com/chart/18694/renewable-energy-employment-worldwide-by-branch/ (accessed on 31 December 2020).

101. Pearce, J.M. Limitations of nuclear power as a sustainable energy source. Sustainability 2012, 4, 1173-1187. [CrossRef]

102. Laureto, J.J.; Pearce, J.M. Nuclear insurance subsidies cost from post-Fukushima accounting based on media sources. Sustainability 2016, 8, 1301. [CrossRef]

103. Schumacher, I. The true cost of disaster insurance makes nuclear power uncompetitive. The Ecologist. 6 February 2014. Available online: https:/ / theecologist.org/2014/feb/06/true-cost-disaster-insurance-makes-nuclear-power-uncompetitive (accessed on 12 January 2021).

104. Zelenika-Zovko, I.; Pearce, J.M. Diverting indirect subsidies from the nuclear industry to the photovoltaic industry: Energy and financial returns. Energy Policy 2011, 39, 2626-2632. [CrossRef]

105. Heidari, N.; Pearce, J.M. A review of greenhouse gas emission liabilities as the value of renewable energy for mitigating lawsuits for climate change related damages. Renew. Sustain. Energy Rev. 2016, 55, 899-908. [CrossRef]

106. Zhang, F. Can solar panels leapfrog power grids? The World Bank experience 1992-2009. Renew. Sustain. Energy Rev. 2014, 38, 811-820. [CrossRef]

107. Schäfer, A.I.; Hughes, G.; Richards, B.S. Renewable energy powered membrane technology: A leapfrog approach to rural water treatment in developing countries? Renew. Sustain. Energy Rev. 2014, 40, 542-556. [CrossRef]

108. Levin, T.; Thomas, V.M. Can developing countries leapfrog the centralized electrification paradigm? Energy Sustain. Dev. 2016, 31, 97-107. [CrossRef]

109. Farrell, J. Minnesota's Value of Solar; Institute for Local Self-Reliance: Minneapolis, MN, USA, 2014.

110. Poullikkas, A. A comparative assessment of net metering and feed in tariff schemes for residential PV systems. Sustain. Energy Technol. Assess. 2013, 3, 1-8. [CrossRef]

111. Taylor, M.; McLaren, J.; Cory, K.; Davidovich, T.; Sterling, J.; Makhyoun, M. Value of Solar. Program Design and Implementation Considerations; National Renewable Energy Lab. (NREL): Golden, CO, USA, 2015. [CrossRef]

112. Munoz, F.D.; Mills, A.D. Endogenous Assessment of the Capacity Value of Solar PV in Generation Investment Planning Studies. IEEE Trans. Sustain. Energy 2015, 6, 1574-1585. [CrossRef]

113. Gami, D.; Sioshansi, R.; Denholm, P. Data Challenges in Estimating the Capacity Value of Solar Photovoltaics. IEEE J. Photovolt. 2017, 7, 1065-1073. [CrossRef]

114. Hayibo, K.S.; Pearce, J.M. A review of the value of solar methodology with a case study of the US VOS. Renew. Sustain. Energy Rev. 2021, 137, 110599. [CrossRef]

115. Prehoda, E.W.; Pearce, J.M. Pearce. Potential lives saved by replacing coal with solar photovoltaic electricity production in the US. Renew. Sustain. Energy Rev. 2017, 80, 710-715. [CrossRef]

116. Schelly, C.; Prehoda, E.; Price, J.; Delach, A.; Thapaliya, R. Ratepayer Perspectives on Mid- to Large-Scale Solar Development on Long Island, NY: Lessons for Reducing Siting Conflict through Supported Development Types. Energies 2020, 13, 5628. [CrossRef]

117. Schelly, C.; Price, J.P.; Delach, A.; Thapaliya, R.; Leu, K. Improving Solar Development Policy and Planning through Stakeholder Engagement: The Long Island Solar Roadmap Project. Electron. J. 2019, 32, 106678. [CrossRef]

118. Dubey, S.; Jadhav, N.Y.; Zakirova, B. Socio-economic and environmental impacts of silicon based photovoltaic (PV) technologies. Energy Procedia 2013, 33, 322-334. [CrossRef] 
119. Markert, E.; Celik, I.; Apul, D. Private and Externality Costs and Benefits of Recycling Crystalline Silicon (c-Si) Photovoltaic Panels. Energies 2020, 13, 3650. [CrossRef]

120. McDonald, N.C.; Pearce, J.M. Producer responsibility and recycling solar photovoltaic modules. Energy Policy. 2010, 38, 7041-7047. [CrossRef]

121. Coughlin, J.; Cory, K. Solar Photovoltaic Financing: Residential Sector Deployment; No. NREL/TP-6A2-44853; National Renewable Energy Lab.: Golden, CO, USA, 2009.

122. Bolinger, M. Financing Non-Residential Photovoltaic Projects: Options and Implications; No. LBNL-1410E; Lawrence Berkeley National Lab. (LBNL): Berkeley, CA, USA, 2009.

123. Feldman, D.; Friedman, B.; Margolis, R. Financing, Overhead, and Profit: An in-Depth Discussion of Costs Associated with Third-Party Financing of Residential and Commercial Photovoltaic Systems; No. NREL/TP-6A20-60401; National Renewable Energy Lab.: Golden, CO, USA, 2013.

124. Alafita, T.; Pearce, J.M. Securitization of residential solar photovoltaic assets: Costs, risks and uncertainty. Energy Policy 2014, 67, 488-498. [CrossRef]

125. Peng, J.; Lu, L.; Yang, H. Review on life cycle assessment of energy payback and greenhouse gas emission of solar photovoltaic systems. Renew. Sustain. Energy Rev. 2013, 19, 255-274. [CrossRef]

126. Kim, J.; Suharto, Y.; Daim, T. Evaluation of Electrical Energy Storage (EES) technologies for renewable energy: A case from the US Pacific Northwest. J. Energy Storage 2017, 11, 25-54. [CrossRef]

127. International Finance Corporation (IFC). Energy Storage Trends and Opportunities in Emerging Markets, International Finance Corporation. 2017. Available online: https:/ / www.esmap.org/sites/default/files/esmap-files/7151-IFC-EnergyStorage-report. pdf (accessed on 12 January 2021).

128. International Renewable Energy Agency (IRENA). Innovation Landscape Brief: Utility-Scale Batteries; International Renewable Energy Agency: Abu Dhabi, United Arab Emirates, 2019.

129. Federal Energy Regulatory Commission (FERC). FERC Order No. 2222: A New Day for Distributed Energy Resources. 2020. Available online: https:/ / www.ferc.gov/sites/default/files/2020-09/E-1-facts.pdf (accessed on 14 November 2020).

130. Awāsis, S. Gwaabaw: Applying Anishinaabe Harvesting Protocols to Energy Governance. Can. Geogr. 2020. [CrossRef]

131. Simpson, Leanne Betasamosake. A Short History of the Blockade: Giant Beavers, Diplomacy \& Regeneration in Nishnaabewin. Kreisel Lecture. 2020. Available online: https://www.cbc.ca/radio/ideas/the-brilliance-of-the-beaver-learning-from-ananishnaabe-world-1.5534706 (accessed on 18 November 2020).

132. Prehoda, E.; Pearce, J.; Schelly, C. Policies to Overcome Barriers for Renewable Energy Distributed Generation: A Case Study of Utility Structure and Regulatory Regimes in Michigan. Energies 2019, 12, 674. [CrossRef]

133. Fresh Energy. N.d. Sample Ordinance and Procurement Language. Available online: https://fresh-energy.org/beeslovesolar/ sample-ordinance-and-procurement-language/ (accessed on 19 November 2020).

134. Nonhebel, S. Renewable energy and food supply: Will there be enough land? Renew. Sustain. Energy Rev. 2005, 9, $191-201$. [CrossRef]

135. Marcheggiani, E.; Gulinck, H.; Galli, A. Detection of fast land. In International Conference on Computational Science and Its Applications; Springer: Berlin/Heidelberg, Germany, 2013; pp. 315-327.

136. Miskin, C.K.; Li, Y.; Perna, A.; Ellis, R.G.; Grubbs, E.K.; Bermel, P.; Agrawal, R. Sustainable co-production of food and solar power to relax land-use constraints. Nat. Sustain. 2019, 2, 972-980. [CrossRef]

137. Mendonça, M.; Lacey, S.; Hvelplund, F. Stability, participation and transparency in renewable energy policy: Lessons from Denmark and the United States. Policy Soc. 2009, 27, 379-398. [CrossRef]

138. Sovacool, B. How long will it take? Conceptualizing the temporal dynamics of energy transitions. Energy Res. Soc. Sci. 2016, 13, 202-215. [CrossRef]

139. Brisbois, M. Powershifts: A framework for assessing the growing impact of decentralized ownership of energy transitions on political decision-making. Energy Res. Soc. Sci. 2019, 50, 151-161. [CrossRef]

140. Hess, D. Energy democracy and social movements: A multi-coalition perspective on the politics of sustainability transitions. Energy Res. Soc. Sci. 2018, 40, 177-189. [CrossRef]

141. Leal-Arcas, R.; Filis, A.; Peykova, M.; Greger, M. Towards a carbon-free, decentralized, and democratized system of energy generation. Connect. J. Int. Law 2019, 35, 129.

142. Galvin, R.; Healy, N. The Green New Deal in the United States: What it is and how to pay for it. Energy Res. Soc. Sci. 2020, 67, 101529. [CrossRef]

143. Whitley, S.; van der Burg, L. Fossil Fuel Subsidy Reform: From Rhetoric to Reality. New Climate Economy, London and Washington, DC. 2015. Available online: https://newclimateeconomy.report/workingpapers/workingpaper/fossil-fuel-subsidyreform-from-rhetoric-to-reality / (accessed on 12 January 2021).

144. Schelly, C.; Louie, E.P.; Pearce, J.M. Examining Interconnection Policy and Net Metering Compensation for Distributed Generation in the United States. Renew. Energy Focus 2017, 22, 10-19. [CrossRef]

145. Hanna, T. Reclaiming Democratic Control: The Role of Public Ownership in Resisting Corporate Domination. J. World Syst. Res. 2019, 25, 42-48. [CrossRef]

146. Scaefer, M.; Olabisi, L.S.; Arola, K.; Poitra, C.M.; Matz, E.; Seigel, M.; Schelly, C.; Adesanya, A.; Bessette, D. Understanding Socio-Technological Systems Changes through an Indigenous, Community-Based Participatory Framework, Working paper; forthcoming. 